\title{
The Effects of Liberalisation of the Passenger Railway Market on the Situation of Regional Rail Connections in Poland, Czech Republic, Slovakia and Austria
}

\section{Jakub Taczanowski ${ }^{1}$}

\begin{abstract}
Liberalisation of railway market can be an important instrument for increasing the attractiveness of local rail services and consequently for making the railways more competitive with other means of transport, which could result in changing the modal share in the favour of railways. The differences in the railway liberalisation level as well as in the policies towards rail transport between Central and Eastern European countries are vast, hence the present situation and the future prospects of regional services are diverse. Whereas there is only one railway line in Slovakia which is not operated by the state railway company ZSSK, a few private local connections which complement a very dense network of C $\mathrm{D}$ state railways are in service in the Czech Republic. Poland, by contrast, is a country where liberalisation of railway market is most advanced as several different companies are responsible for transport in the regions. However, the results of this large scale liberalisation are ambiguous as the positive effects (reopening of some lines) are balanced by isolation of the new regional governmentowned systems from each other. In Austria, by contrast, the existence of several private and regional government-owned local railways which are an indispensable part of the regional transport networks has contributed to maintain an effective transport system. Although the effects of liberalisation on the local railway networks can often be ambiguous, several cases from the Czech Republic, Austria and Poland show that privatisation and municipalisation may have a positive effect on the railway service as it has enabled to maintain the service on many sections which were at risk of closure. However, the most important condition of the effective transport development seems to be an active cooperation between the railway operators and the local governments as an expression of appropriate transport policy.
\end{abstract}

Key words: rail transport, railway liberalisation, regional railway lines, Central Europe JEL Classification: R40

Received: 15 October 2014 / Accepted: 14 August 2015 / Published: 30 September 2015

\footnotetext{
${ }^{1}$ Jagiellonian University in Kraków, Institute of Geography and Spatial Management, 30-387 Kraków, ul. Gronostajowa 7, Poland, e-mail: jakub.Taczanowski@uj.edu.pl

(C) 2015 by the authors; licensee Review of Economic Perspectives / Národohospodárský obzor, Masaryk University, Faculty of Economics and Administration, Brno, Czech Republic. This article is an open access article distributed under the terms and conditions of the Creative Commons Attribution 3.0 license, Attribution - Non Commercial - No Derivatives.
} 


\section{Introduction}

The liberalisation of the railway market - understood as opening of the railway sector to several operators including non-state-owned companies - is one of the most important tendencies in the contemporary transport development in the European Union. It is seen as an instrument which should contribute to make railway transport more efficient and competitive both in passenger and freight services. This policy of creating a common railway market - which is formulated in several EU directives as "railway packages" aims to revitalise railway transport in order to make it more attractive and to try to reverse the negative trend of its modal market share (Deville and Verduyn, 2012, p. 5). In fact, liberalisation (or deregulation) started at the national level (e.g. Sweden) as early as in the 1960s as a response to the requirements of individual modes of transport (Knowles and Hall, 2000, p. 76). Separation of infrastructure from railway operations is the crucial element which enables competition in rail transport (Tomeš, 2006, p. 98). This competition may have a different character; in fact there are three modes of competition: 1) Competition in the market between vertically integrated rail companies (as in North American goods trains services); 2) competition in the market between train operating companies with regulated access to track infrastructure (which may or may not be owned by one of the companies providing train services); and finally, 3) competition for the market between rail companies which is connected with competitive tendering (Finger 2014, p. 279). In the European Union, the second and third model can be observed, however, with significant differences between countries. At present, it can be assumed that liberalisation is an inevitable process which is a natural step in the transport development in Europe (Ostapowicz, 2012, p. 78). Bošković and Bugarinović (2015, p. 50) claim even that there is no alternative to restructuring and privatization of the European railways. However, despite common European Union policy, the differences in the actual railway liberalisation level as well as in the policies towards rail transport between several European countries are significant because the states apply the common European regulation at their own internal situation (Beria at al., 2010, p. 26). Whereas some EU members still have not opened their markets (e.g. France, Spain), others (e.g. Great Britain, Sweden) are characterised by high levels of liberalisation (Rail Liberalisation Index 2011, 2011). The case of the UK is particular as this country was one of the first to have decided to liberalise and privatise the rail market on a big scale, which turned out to bring ambiguous and controversial consequences - besides positive effects also deterioration of rail infrastructure and transformation of state monopoly into privately-owned regional ones (Knowles, 1998, Bradshaw, 2001, Charlton et al, 1997). It should be emphasised that all analysed Central-European countries have different institutional models of railways. Poland and Austria have decided to introduce holding companies (German model), whereas the Czech Republic has followed the French solutions (separation of key powers), and Slovakia has chosen complete separation (British model) (Finger 2014, p. 281). The problem of opportunities and threats connected with rail liberalisation in countries of Central Europe was analysed inter alia by Tomeš (2006), Milczarek (2012), Ostapowicz (2012), Górny (2013), Baresch (2013), and Gütermann (2013).

The liberalisation of passenger rail services refers to several elements of railway networks - interregional connections (including high speed trains) as well as regional and local lines. Their character - and consequently often also the mode of competition 
(mode 2 versus mode 3, see above) - are essentially different because the former - often the only profitable elements of the passenger railway systems - are a lucrative market for several competing companies, whereas the latter are frequently operated mainly due to reasons which are not purely economic. In practically all European countries, the role of local railways has diminished over the last decades, in some, e.g. in Poland, the decline has been massive (Taylor, 2007, p. 183; Komusiński, 2010, p. 94). However, the saddling of the regional governments with responsibility for local transport has created new conditions for the competition also at this level as rail services have been put out to tender. This may be a chance for new prospects for the future for at least some local railway lines.

The aim of the article is to answer the question whether the liberalisation of railway markets in Poland, Czech Republic, Slovakia, and Austria has a positive effect on their regional rail networks. In order to discuss this problem, the article presents the current situation of regional rail services as well as the contemporary tendencies towards rail privatisation at the regional level in examined countries.

The paper analyses only regular regional passenger railway services thus tourist and heritage lines (e.g. seasonal weekend connections Sędzisław - Trutnov from Poland to the Czech Republic and all narrow gauge lines in Poland) are excluded.

\section{Methods}

The methods used in the paper are strictly connected with the comparative analysis of private and regional-owned local railway systems of four examined countries. According to the classification of methods used in transport geography, which were proposed by Rodrigue (2013), the analysis of flows in the networks as well as cartographic methods and graphs are used. The second element is the analysis of statistical data about the number of trains, journey times, modal split of rail and rail passengers (when available) which enables to evaluate better the not only spatial but also economic results of liberalisation.

\section{Regional Railway Lines in the Networks of Poland, Czech Republic, Slovakia, and Austria}

The delimitation of regional (or local) railway lines - especially in the analysis which considers several countries - is not unequivocal as no universal international criteria exist. However, lines of this type have some common characteristics which make it possible to identify them. They can be defined as not belonging to any network of national significance and characterised by relatively low technical parameters (a low minimum curve radius, a high maximum gradient and low quality of the track). In Central Europe, local railway lines were mostly built between about 1880 and 1914, once the main networks had been constructed. The main aim of local railways was to connect towns of local importance, industrial plants or tourist resorts with the main railway line (Taczanowski 2012, p. 126).

The railway networks of Austria, Czech Republic, Slovakia and south-eastern Poland were built in the same basic political and economic circumstances as these territories 
were part of the Austro-Hungarian Empire before 1918. However, from 1945, and after the socio-economic transformation of 1989 in particular, their situation has differed significantly. The railway networks of transition countries - Poland, Czech Republic and Slovakia (before 1993 Czechoslovakia) - had to face the challenges of new economic conditions, and it were the local railways which felt their results in a particularly clear way. The reaction of rail transport - which was then completely nationalised - on the new demands of free market in the three countries turned out to be completely different. Whereas the Czech Republic has maintained a dense rail system including several local connections, the development of the Polish State Railways after 1989 is characterised by a massive decline. Slovakia which maintained its relative dense railway network until 2003 decided to downsize its system although the scale of this process is significantly smaller than in Poland. The situation in Austria - which obviously did not experience any socio-economic transformation - can be also described as intermediate with significant regional differences.

\section{The Regional Railway Liberalisation in Poland}

The first steps in the liberalisation process of the Polish State Railways (PKP) was made in 1991 - two years after the beginning of the socio-economic transformation - when the national company divested over 70 of its businesses, mainly constructing and track repairing companies. However, it was just in 2000 after the law about commercialisation, restructuring and privatisation of the PKP had been passed, that the liberalisation of rail services actually began. ${ }^{2}$ Consequently, the PKP was divided into several companies including PKP PLK responsible for the infrastructure, PKP IC (Intercity connections), PKP PR (regional services) and PKP SKM (suburban railways in Gdańsk area) (Górny, 2013, p. 18). At the same time, the regional governments (voivodeships) were saddled with responsibility and financing of the regional rail transport.

An important change was brought about by the amendment to the commercialisation law passed in 2008 which divested the regional services from the national railway company and made the regional governments their owner. Górny (2012, p. 36) emphasises that it is a unique and controversial solution. However, organisational and financial problems with the PR company - to a great extent connected with the fact that it had 16 owners - lead some regional governments to decisions to create their own local rail companies. The first one was the Dolnośląskie voivodeship in 2007 followed by regions: Wielkopolskie in 2009 and Śląskie voivodeship in 2010 (the company Koleje Śląskie started to operate in 2011) (http://koleje-wielkopolskie.com.pl, 2014, www.kolejedolnoslaskie.eu, 2014, http://kolejeslaskie.com, 2014). The next voivodeships to operate their own railway companies are Łódzkieand Małopolskie, respectively in June and December 2014 (http://lka.lodzkie.pl, 2014 and http://www.malopolskie.pl,

\footnotetext{
${ }^{2}$ However, the first regional railway operator which was not owned by the state - Lubuska Kolej Regionalna (LKR) - was created as early as in 1992. It took over several lines in Western Poland (contemporary voivodeships Lubuskie and Wielkopolskie) but the service was stopped already in 1994 because of economic loss, legal problems and the policy of the PKP which refused to open its infrastructure for LKR trains (Górny, 2013, p. 28).
} 
2014). A different situation is characteristic for the Mazowieckie voivodeship, where as early as in 2004 the company Koleje Mazowieckie was created as a common property of PKP PR and the regional government. Since 2008, the voivodeship has a 100\% stake in the company (www.mazowieckie.com.pl, 2014).

Arriva, a company which belongs to the German Railways DB is the only example of an external regional rail company which managed to enter the Polish market. In 2007 it began to operate several regional lines in the Kujawsko-Pomorskie voivodeship (http://www.arriva.pl, 2014).

Figure 1 Regional railway lines in Poland which are operated by companies different from the PKP IC and PR in 2014

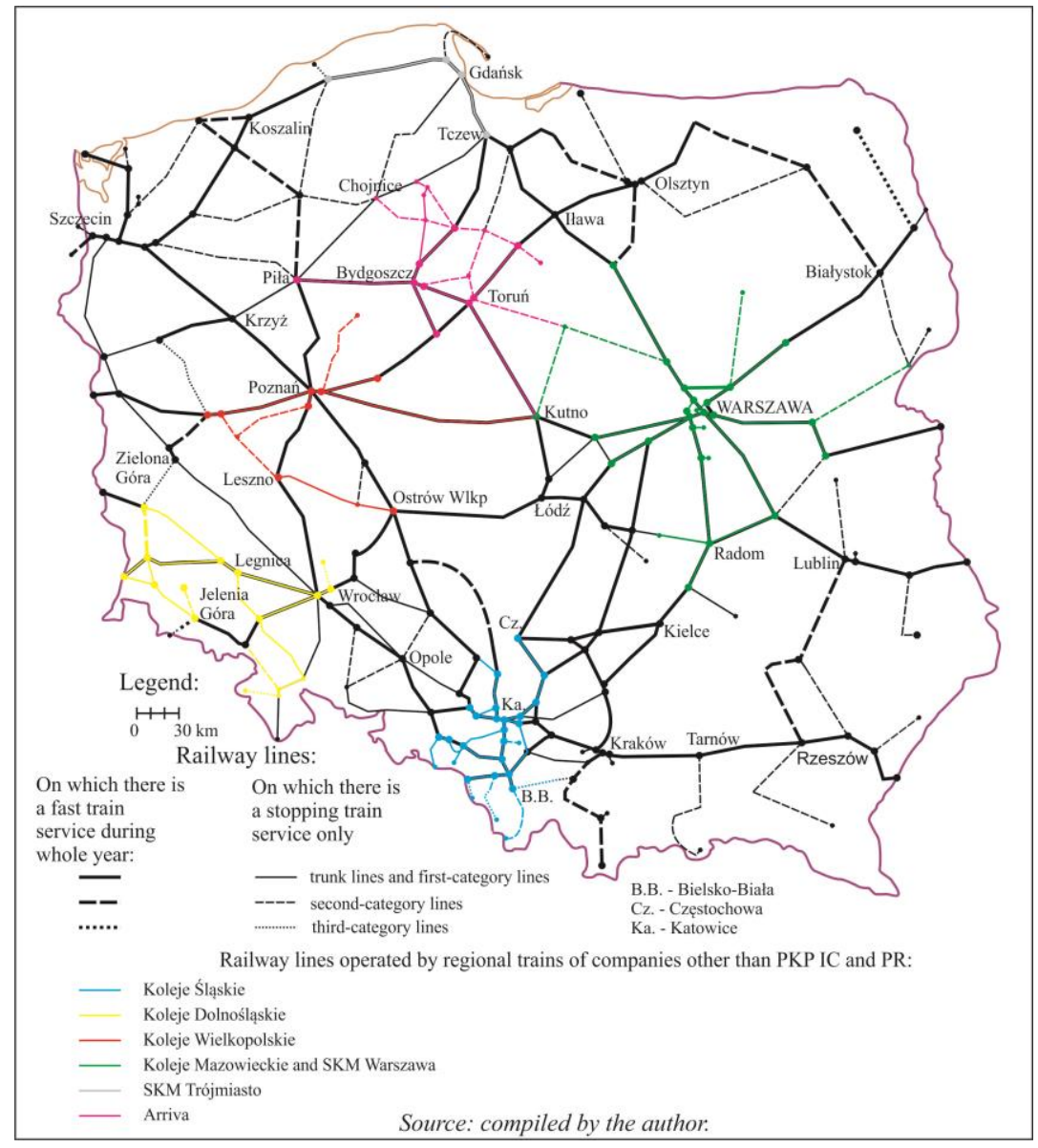

Source: compiled by the author. 
Table 1 The Polish railway network in 2014

\begin{tabular}{lcr}
\hline \multicolumn{1}{c}{ Type of line } & $\begin{array}{c}\text { Total } \\
\text { length } \\
{[\mathrm{km}]}\end{array}$ & $\begin{array}{c}\text { Of which operated by } \\
\text { companies different from } \\
\text { the PKP IC and PR [km] }\end{array}$ \\
\hline Trunk lines and first-category lines with fast trains & 6,272 & 2,214 \\
Trunk lines and first-category lines with stopping trains only & 1,885 & 693 \\
Second-category lines with fast trains & 1,079 & 48 \\
Second-category lines with stopping trains only & 2,962 & 1,114 \\
Third-category lines with fast trains & 132 & 0 \\
Third-category lines with fast trains with stopping trains only & 306 & 123 \\
TOTAL & 12,636 & 4,192 \\
\hline
\end{tabular}

Source: compiled by the author.

Other companies which are external from the national long distance train company PKP IC and regional-owned firm PR: WKD, Szybka Kolej Miejska w Warszawie and UBB are not analysed in this paper. WKD and Szybka Kolej Miejska w Warszawie provide rail services on suburban lines in the Warsaw agglomeration. The first company operates on a line with light rail character, technically completely separated from the national railway network and therefore is excluded from the present analysis. The latter company is responsible for suburban lines in the Warsaw metropolitan area, most of which is also operated by the Koleje Mazowieckie company and that is why the both are analysed together. Finally, the UBB operated local trains on the line from Świnoujście to Heringsdorf in Germany, of which only $1.4 \mathrm{~km}$ is situated in Poland.

The liberalisation seemed to have been a chance for at least some narrow gauge railway lines to be reopened. All of them were closed down by the PKP in 2001. Although the company SKPL took over three lines of this type on which it reintroduced regular passenger train, the experiment failed and they were closed down between 2006 and 2010 (Pawłowski, 2012, p. 203, 204). Regional railway lines which are operated by companies different from the PKP IC and PR are presented on fig. 1 and in table 1.

Regional railway lines which are operated by companies different from the PKP IC and PR are mostly situated in regions of Western Poland where the railway network - despite a very significant scaling down after 1989 - is still better developed as these provinces were part of Germany before 1945/1918. Only in the Mazowieckie and KujawskoPomorskie voivodeships, all regional lines are served by trains which belong to the regional-owned companies. In the other voivodeships (Śląskie, Dolnośląskie, Wielkopolskie and particularly Pomorskie) just the central parts of the regions are served by these companies, whereas only PR regional services operate in the peripheries (fig. 1).

\section{The Regional Railway Liberalisation in the Czech Republic}

Railway Act (Czech Zákon o dráhách č. 266/1994) from 1994 was the act which enabled railway liberalisation in the Czech Republic. Consequently, the liberalisation of regional railway lines started in the second half of the 1990s, when some local lines in the Sudets (Czech Sudety or Krkonošsko-jesenická subprovincie) and Ore Mountains (Czech Krušné hory) were taken over from the Czech Railways C̆D by private companies (see fig. 2 and tab. 2). 
The circumstances of the takeover were significant in the case of lines Šmperk - Sobotín / Kouty nad Desnou and Milotice nad Opavou - Vrbno pod Pradědem which had been seriously damaged in the flood in 1997 and the ČD and the Ministry of Transport were not interested in their reconstruction due to high costs of repair works and the consequent maintenance of this purely local connection. However, the pressure of the local communities and the interest of rail companies external from the state railways led to the reopening of the line. In the case of the Sumperk - Sobotín / Kouty nad Desnou line from its reopening in 1998 the operator was the firm which reconstructed the line Stavební obnova železnic. However, in 2002 it changed into Connex Morava (then Veolia Transport Morava and now Arriva Morava) (http://www.sart.cz/zeleznicedesna/historie, 2014). The line Milotice nad Opavou - Vrbno pod Pradědem was reconstructed and consequently taken over by OKD - one the most important Czech freight rail companies (http://spz.logout.cz/trate/vrbno.html, 2014). In 2010, it was replaced by Viamont which was taken over by GTW Train Regio in 2011.

GTW Train Regio (before 2011 as Viamont) operates on the local lines: Trutnov - Svoboda nad Úpou (from 1997), Sokolov - Kraslice (from 1998, in 2000 the cross-border section to Klingenthal in Germany was reopened after 55 years), Karlovy Vary Mariánské Lázně (from 2006) and Harrachov - Szklarska Poręba Górna (a cross-border line to Poland reopened in 2010 after 52 years). GTW Train Regio operates also seasonal weekend trains on another Czech-Polish railway line - the one Trutnov - Královec Lubawka - Sędzisław, also reopened for the first time after the second world war (http://www.gwtr.cz, 2014, http://www.zelpage.cz/trate/ceska-republika, 2014).

Figure 2 Regional railway lines in the Czech Republic which are operated by companies different from the ČD in 2014

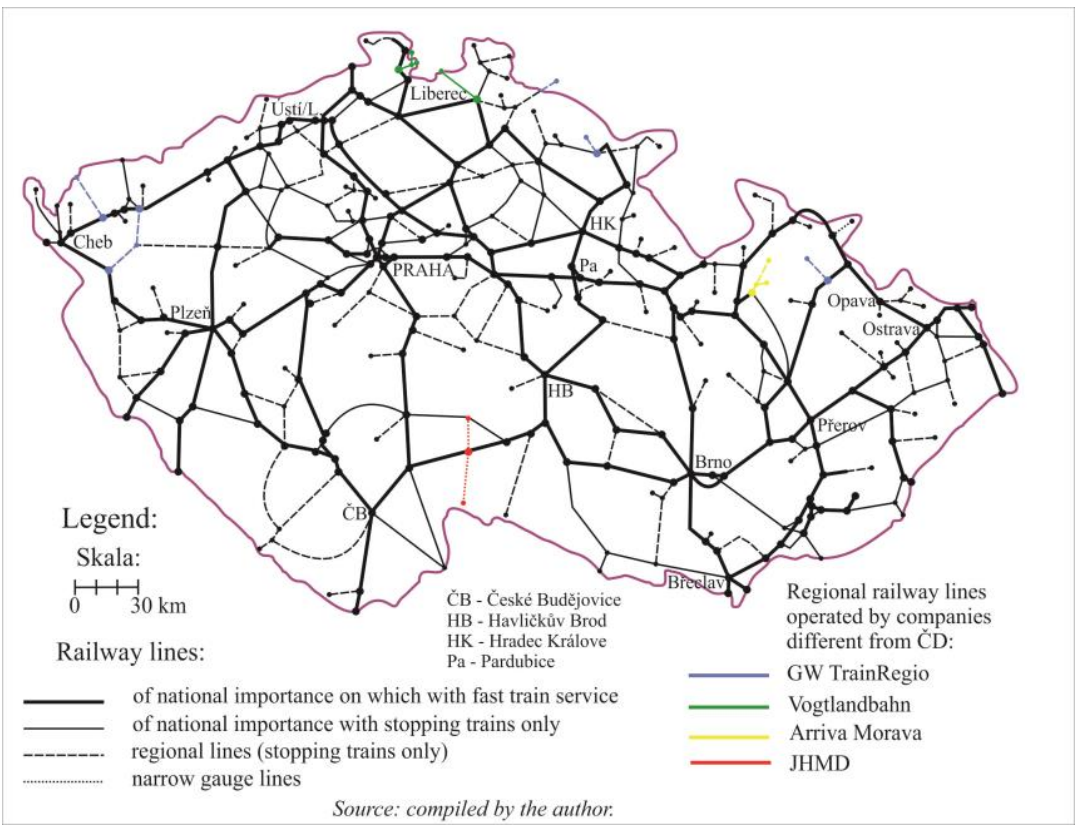

Source: compiled by the author. 
Table 2 The Czech railway network in 2014

\begin{tabular}{lrr}
\hline \multicolumn{1}{c}{ Type of line } & $\begin{array}{c}\text { Total } \\
\text { length } \\
{[\mathrm{km}]}\end{array}$ & $\begin{array}{c}\text { Of which regional lines and lines of } \\
\text { national importance with stopping } \\
\text { trains only operated by companies } \\
\text { different from the ČD [km] }\end{array}$ \\
\hline Lines of national importance with fast trains & 3,954 & \\
Lines of national importance with stopping trains only & 1,947 & - \\
Regional lines (with stopping trains only) & 2,614 & 61 \\
Narrow gauge lines & 99 & 140 \\
TOTAL & 8,614 & 79 \\
\hline
\end{tabular}

Source: compiled by the author.

The German company Vogtlandbahn operates from 2010 local trains on the line Liberec

- Rybniště via Zittau in Germany with the branch line Varnsdorf - Seifhennersdorf which also crosses the Czech-German border.

Two of three Czech narrow gauge lines are also operated by a private company (fig. 2). The JHMD took over the lines Jindřichův Hradec -Nová Bystřice and Jindřichův Hradec - Obratan̆ in 1997 as the state railways saw the service as "uneconomical" (http://jhmd.cz/o-nas/historie, 2014).

\section{The Regional Railway Liberalisation in Slovakia}

The first attempts to open the Slovak railway market were connected with closure of several regional lines which had been decided by the Slovak State Railways ZSSK in 2003. In order to maintain the passenger service on two lines in the Bratislava region Zohor - Záhorská Ves, and Zohor - Plavecký Mikuláš - a new company - Bratislavská regionálna kol'ajová spoločnost' - was created by the regional government. The new operator took over the both lines from the ZSSK but the passenger service was stopped due to high fees for using the infrastructure and bad state of the rolling stock (Rok zmien 2011: Liberalizácia trhu osobnej železničnej dopravy, 2014).

In 2011, after the eight-year long absence of any private or regional passenger railway company in Slovakia, the service on the local line Bratislava - Komárno was taken over by the company RegioJet which had signed a contract with the Ministry of Transport, Construction and Regional Development. At present, it is the only regular passenger service in the country which does not belong to the state railways ZSSK.

\section{The Situation of Regional and Private Regional Railway Lines in Austria.}

The situation of the rail market in Austria is significantly different from Poland, Czech Republic and Slovakia as the concept of private and regional government-owned railways in this country has a long tradition which was not interrupted after 1945. Several companies were created between the 1880 s and 1918 by the regional governments in the whole Austro-Hungarian Empire in order to build local normal- and narrow gauge local lines. The majority of those situated on the contemporary Austrian territory are still in service. The normal- and narrow gauge lines operated by Steiermärkische Landesbahnen (StLB) in Styria and Stern\&Hafferl in Upper Austria form efficient local transport systems which complement the state network. Separate private and regional govern- 
ment-owned lines exist in the provinces (Bundesland) of Salzburg, Tyrol, Vorarlberg, Lower Austria and Burgenland (in the latter the Austro-Hungarian railway company GySEV) (fig. 3 and 4). All these regional railways are an important part of the Austrian transport system as they act as feeders for long-distance railway lines, serve as vital line of transport in their regions and contribute to an increase of their economic attractiveness (Gütermann, 2013, p. 3 and 41).

Of $710 \mathrm{~km}$ of regional railway lines which do not belong to the Austrian Federal Railways, ÖBB, only $183 \mathrm{~km}$ are sections which were taken over from the ÖBB after 2000: the both narrow gauge lines in Lower Austria (St. PöltenHbf. - Mariazell, and Waidhofen/Ybbs - Gstadt) from 2010 operated by the regional company NÖVOG, the narrow gauge line Zell am See - Krimml in the Salzburg province which has belonged to the regional government since 2008 and is operated by the company Salzburger Lokalbahn, and the section Ehrwald - Pfronten Steinach in Tyrol which is isolated from the Austrian network and was taken over by the German State Railways DB in 2003 (www.noevog.at, 2014; www.pinzgauerlokalbahn.at, 2014).

The case of the takeover of the Zell am See - Krimml line from the state railways is similar to the Czech local railways Šumperk - Sobotín / Kouty nad Desnou and Milotice nad Opavou - Vrbno pod Pradědem. The last, 24 kilometre-long section Mittersill Krimml was damaged by floods in 2005, and the Austrian Federal Railways did not have any intention to rebuild it. The reconstruction took place only in 2010 after the line had been taken over by the local government which had awarded an operating contract to Salzburger Lokalbahn.

The narrow gauge lines in Lower Austria were also seen as "uneconomical" by the national rail operator who decided to dispose of them. In 2010 they were taken over by the regional government but - unlike in the case of Salzburg province - it did not result in any reopening of the sections which had been closed before. What is more the branch line Ober Grafendorf - Mank was closed for passenger traffic immediately after the takeover.

\section{The effects of Liberalisation on the Regional Rail Traffic in Poland, Czech Republic, Slovakia and Austria}

\section{The General Situation of the Operated Networks}

In Poland, the railway liberalisation was put into practice after at least 15 years of a serious crisis of the Polish State Railways. Although the idea of divesting the national operator into different firms - and the separation the operators from the rail infrastructure in particular - was analogous to the decisions made in other European countries including the Czech Republic, Slovakia and Austria - the reform was certainly carried out in an inappropriate and chaotic way. Especially the peculiar decision to saddle the regional governments with the responsibility for the regional railway services company brought several problems, particularly just after 2008. One of the most problematic questions is the operating of regional trains which cross the borders of voivodeships. The lack of several connections of this type is very noticeable on the fig. 1 . 
Figure 3 Regional railway lines in Austria which are operated by companies different from the ČD in 2014

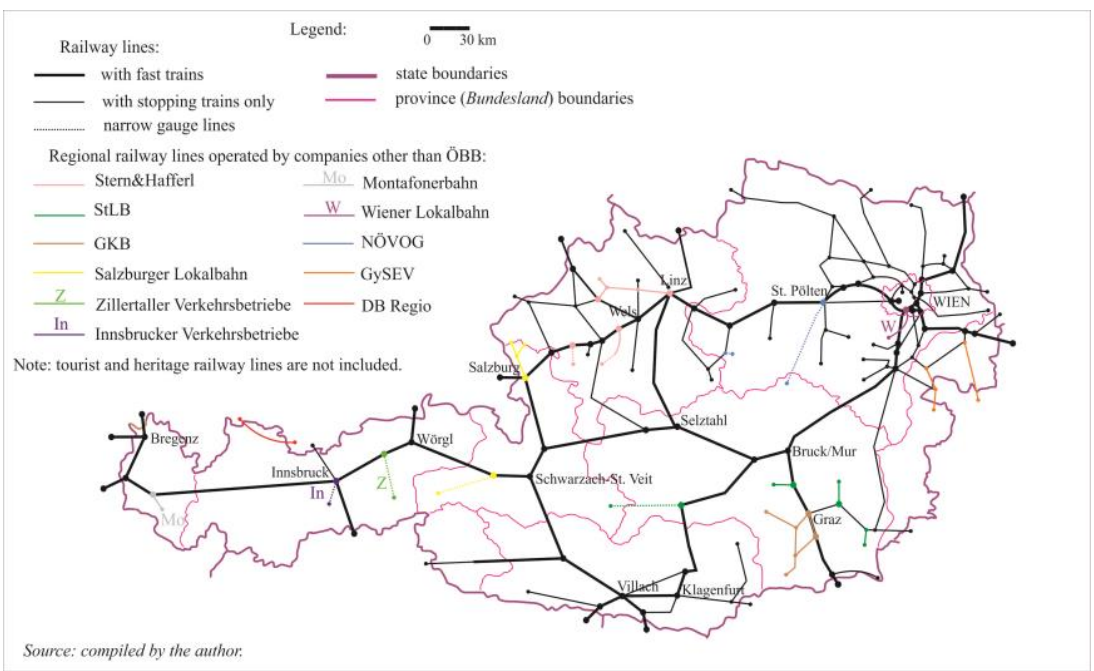

Source: compiled by the author.

Figure 4 The share of private and regional government-owned regional railway lines in the Austrian railway network

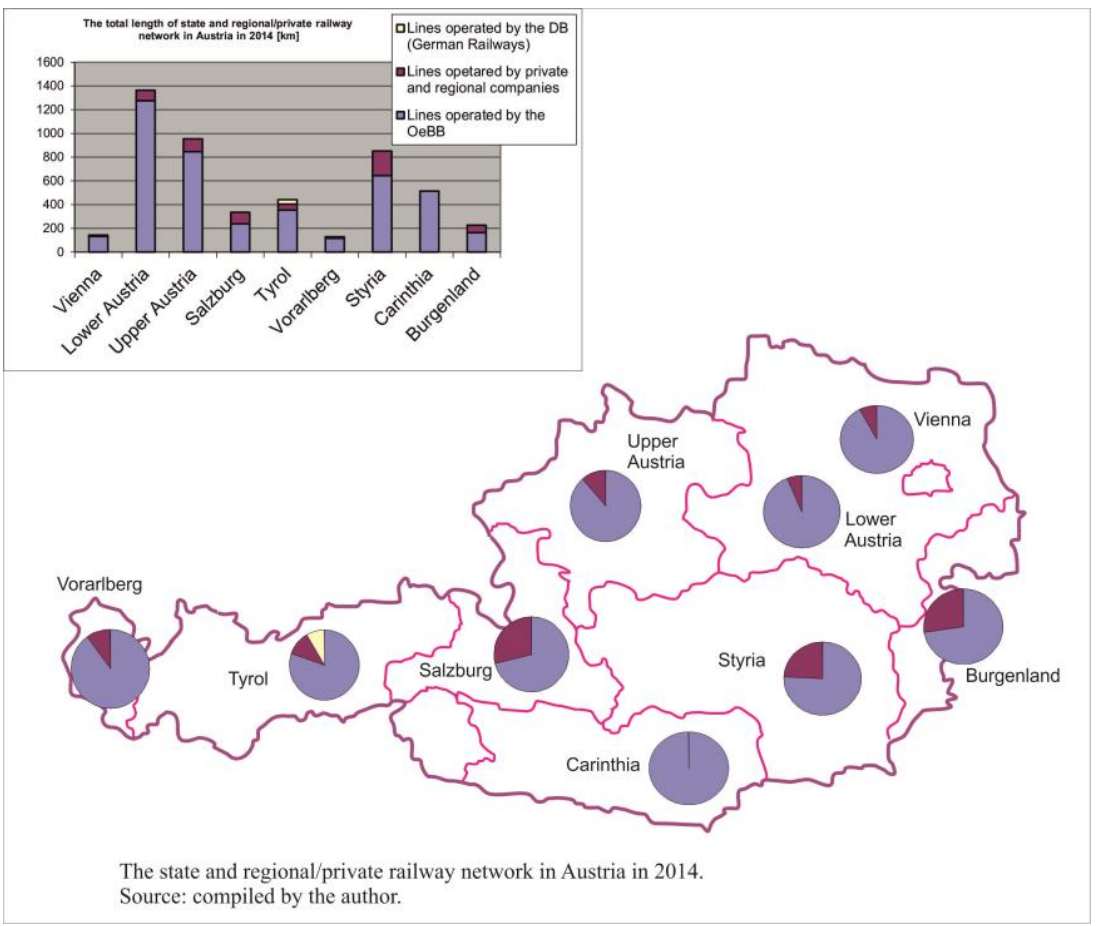

Source: compiled by the author. 
What is more, the rail transport inside the regions did not benefit from the new situation in many cases either. Increasing economic difficulties of the PR company as well as disputes between the governments of several regions led many voivodeships to create their own railway companies.

However, the result of this peculiar competition between the PR company which is owned by 16 Polish voivodeships and new regional-owned firms like Koleje Śląskie has been rather chaos than any improvement, especially because of the lack of common tariffs. It is characteristic that many of the new operators have decided to take over only the most lucrative lines in the metropolitan areas and not railways in peripheral areas. The plans of new companies in the Łódzkie and Małopolskie voivodeships raise similar doubts. However, in some voivodeships - in particular Dolnośląskie - the new regionalowned companies have enabled to reopen some local lines which had been closed before e.g. Wrocław -Trzebnica, Kłodzko - Wałbrzych or seasonal weekend connection Sędzisław - Trutnov.

The situation in the Mazowieckie voivodeship, where the regional railway company Koleje Mazowieckie (KM) was created earlier in a different way - not as competition to the PR but instead of it - is significantly better. It is reflected in the rising number of passengers (see below). In the Czech Republic, the scale of regional railway liberalisation is much smaller, however, it seems that its influence on the local railway network is not insignificant. The takeover of the two mountain lines which had been damaged in the flood in 1997 as well as two narrow gauge sections which had been seen as "uneconomical" by the state railways was the only chance to maintain these connections. Unlike in the case of Polish narrow gauge lines, the Czech lines managed to become an important part of the regional transport system. The situation of other privatised regional lines e.g. Liberec - Rybniště or Karlovy Vary - Mariánské Lázně is different as their existence was not at risk and the privatisation was the element of the gradual opening of the market and introducing the competition for the state railways.

As the railway liberalisation in Slovakia has just started and it is limited only to one line, it is too early to be able to evaluate its effects on the regional rail transport in the country. A question arises whether it may be possible to use it as an instrument which could enable to reopen some closed local lines as it was attempted with no success in 2003.

In Austria, the evaluation of the effects of private and regional-owned lines on the local transport system applies not only to the recent phenomenon but also to the system which has existed since the end of the 19th century. Private and regional government-owned lines have played an important role in the local transport systems and are still their vital element. Although some of them were closed down after 1945, it seems that generally these lines have been more resistant to closure than similar lines which belonged to the Austrian Federal Railways. Whereas all state-owned narrow gauge lines were closed or taken over by other companies, the vast majority of private and regional lines is still in service. It would confirm the thesis that private and regional government-owned railway companies are more efficient and flexible as the state railways and thus react better on the demand on the market.

The comparison between two narrow gauge lines situated in Alpine valleys which are very important tourist regions is significant. The first one - Zell am See - Krimml (54 
$\mathrm{km}$ long) - in the last year of the state railway service (2008), it was operated by 7 pairs of trains on the whole distance (18 on the suburban section in Zell am See), but buses were used on the final $24 \mathrm{~km}$ long section because the track had been damaged by floods. At the same time, a very similar railway Jenbach - Mayrhofen in the Tyrol (32 km long) was served by 17 pairs of trains on the whole distance. Instead of rolling stock from the 1960s, modern push-pull trains were used.

Reopening of maintenance of some local railway lines which were at risk of closure is certainly an important geographical aspect in rail liberalisation in Poland, Czech Republic and Austria. A question arises to which extent the scaling down of regional railways - which after 1989 has been characteristic especially (but not only) for Poland - can be stopped by opening the rail market to external companies. The closures of local lines have usually been caused by high maintenance costs of infrastructure and train service on connections used by a limited number of passengers. From the point of view of national railway companies, these lines were seen as "uneconomical" in the free market economy, that is unlike the main connections which could bring profit. In Poland in particular such a purely profit-oriented attitude towards railways (and public transport in general) could be observed immediately after 1989. However, it should be emphasised that no alternative proposals to closure were taken into consideration in many cases (e.g. purchase of light diesel carriages instead of heavy locomotives, improvements of the infrastructure, and timetables). What is more, the decisions to close down railway lines were rarely consulted with local authorities and residents. It seems that the closures often did not meet the financial expectations as they resulted in the decline in the number of passengers on other lines and in general decrease of positive image of rail. A continuation of scaling down which contributed to a creation of a vicious circle was the only possible consequence.

That is why many (but not all) local lines which have been closed down have a certain potential. However, it can be exploited to a much greater scale by region-oriented railway companies than by national operators. It is not coincidence that non-state-owned local railways in Austria have ended up being more immune to closures between 1960s and 1980s than the lines operated by the Federal Railways. The more cost-effective way of running the companies owned by the regional governments or private firms and their better integration in the local communities have made it possible to maintain most of these connections. At present, the same phenomenon can be observed on some Polish and Czech lines which are operated by local authorities or external companies. Undoubtedly, the costs of maintenance and - in particular - reopening of these lines are significant. For instance, reopening of $13.3 \mathrm{~km}$ long section from Szklarska Poręba Górna to the Polish-Czech border in 2009-2010 costed 14 million zł (about 3.3 million euro), however, as much as $85 \%$ was financed from EU grants (http://www.euroregionnysa.pl). Such a significant external aid is the rule as far as rail-based transport projects are concerned. It should be emphasised that the generally high costs of railway infrastructure, rolling stock and services are often seen as to high if compared to alternative (road) transport. However, external (e.g. social, environmental) costs of car/bus transport which are much higher are usually not taken into consideration. 


\section{The Number of Connections and the Quality of the Service}

As the main reason for the opening of the local railway sector for new companies has been to lower the regional government subsidies (the tenders won by Arriva in the Kujawsko-Pomorskie voivodeship and Viamont / GTW Train Regio in the Karlovarský kraj provide good examples of the role of the price offered by the new companies) the number of connections or journey times could not be modified on a larger scale. That is true particularly about some Polish lines where the state of the infrastructure and limited financial resources of the voivodeships could not bring significant improvement (table 3). The situation in the Mazowickie voivodeship as well in the Czech Republic seems better, but not so much in terms of journey times.

Table 3 The number of pair of trains and journey times on the selected regional railway lines in Poland and in the Czech Republic before and after the liberalisation

\begin{tabular}{|c|c|c|c|c|c|}
\hline \multirow[b]{2}{*}{$\begin{array}{c}\text { The line } \\
\text { The contemporary } \\
\text { operator }\end{array}$} & \multirow[b]{2}{*}{$\begin{array}{l}\text { Length } \\
{[\mathrm{km}]}\end{array}$} & \multicolumn{2}{|c|}{$\begin{array}{c}\text { Number of regional trains on } \\
\text { working days }\end{array}$} & \multicolumn{2}{|c|}{ Journey times [min] } \\
\hline & & $\begin{array}{l}\text { In the last } \\
\text { year of the } \\
\text { state service }\end{array}$ & $\begin{array}{l}\text { In the private/ } \\
\text { regional } \\
\text { service }\end{array}$ & $\begin{array}{l}\text { In the last } \\
\text { year of the } \\
\text { state service }\end{array}$ & $\begin{array}{l}\text { In the } \\
\text { private/ } \\
\text { regional } \\
\text { service }\end{array}$ \\
\hline $\begin{array}{l}\text { Jelenia Góra - Lwówek } \\
\text { Ślaski } \\
\text { Koleje Dolnośląskie }\end{array}$ & 33 & 5 & 4 & 58 & 74 \\
\hline $\begin{array}{l}\text { Żywiec-Zwardoń } \\
\text { Koleje Śląskie }\end{array}$ & 37 & 11 & 12 & 67 & 60 \\
\hline $\begin{array}{l}\text { Wyszków - Ostrołęka } \\
\text { Koleje Mazowieckie }\end{array}$ & 54 & 3 & 9 & 70 & 71 \\
\hline $\begin{array}{l}\text { Leszno - Wolsztyn } \\
\text { Koleje Wielkopolskie }\end{array}$ & 47 & 7 & 6 & 57 & 59 \\
\hline $\begin{array}{l}\text { Bydgoszcz - Chełmża } \\
\text { Arriva }\end{array}$ & 47 & 7 & 4 & 57 & 57 \\
\hline $\begin{array}{l}\text { Karlovy Vary dolní } \\
\text { nádraží- Mariánské } \\
\text { Lázně } \\
\text { GTW Train Regio }\end{array}$ & 53 & 8 & 9 & 90 & 80 \\
\hline $\begin{array}{l}\text { Liberec-Rybniště } \\
\text { Vogtlandbahn }\end{array}$ & 56 & 5 & 8 & 80 & 80 \\
\hline
\end{tabular}

Source: compiled by the author on the basis of: Sieciowy Rozkład Jazdy Pociagów (Polish Railway Timetable) 2004, 2005, 2006, 2007, 2008, 2009, 2010, 2011 and www.arriva.pl, www.jizdnirady.nanadrazi.cz, www.kolejedolnoslaskie.eu, http://kolejeslaskie.com, http://kolejewielkopolskie.com.pl and http://www.mazowieckie.com.pl.

However, quality of the service is also an important issue. It is perceived by the passengers not only on the basis of the number of connections and the journey time but is particularly strongly connected with the rolling stock (low-flow carriages/electric or diesel units, air conditioning, ticket machines etc.). The improvement of the comfort of trains in service seems the most positive aspect of rail liberalisation in the analysed 
countries. It applies especially to Poland where the neglect from the communist period and the 1990s were particularly big and any light rolling stock indispensable for economic services was lacking on local lines. The division of the PKP and the consequent liberalisation of the market together with the appearance of UE grants have enabled the voivodeships to purchase the first modern diesel carriages and then also electric units which have contributed not only to the improvement in terms of comfort, but by replacing heavy locomotives which often used to pull one or two carriages it has also rationalised the service from the economic point of view. It is not surprising that the regional governments are much more interested in investments in the rolling stock for their own companies than for the PKP Przewozy Regionalne, whose decisions they could hardy influence. As a result, a vast majority of trains provided by the Polish non-PKP rail operating companies is served by modern rolling stock build or have been modernised in the past 10 years (table 4 ).

Table 4 The rolling stock of the Polish non-PKP railway companies build after 2000. Dates for the year 2014

\begin{tabular}{cccc}
\hline Company & Electric locomotives & Electric units & Diesel carriages \\
\hline Koleje Ślaskie & - & 25 & 3 \\
Koleje Dolnośląskie & - & 11 & 21 \\
Koleje Wielkopolskie & - & 22 & 18 \\
Koleje Mazowieckie & 11 & 26 & 7 \\
SKM Warszawa & - & 32 & - \\
Arriva & - & - & 24 \\
\hline
\end{tabular}

Source: compiled by the author on the basis of the webpages of the companies and www.psmkms.krakow.pl.

Notice: in some cases (e.g. Koleje Wielkopolskie) the owner is not a company but the voivodeship.

However, these changes happened about 20 years too late to be capable of maintaining a dense local railway network in Poland - differently than in the Czech Republic and partially also in Slovakia and Austria, where light diesel carriages have been in service on large scale at least since 1960s.

That is why the impact of rail liberalisation on the quality of the service in these countries has not been as significant as in Poland. The rolling stock used by Czech non- ČD rail companies is usually similar to those of the state monopolist (diesel carriages class 810). However, the positive influence of rail liberalisation on the rolling stock can be observed in Austria, where after the takeover of the Zell am See - Krimml narrow gauge line by the Salzburg regional government, the section to Krimml was reopened and modern push-pull trains were purchased (www.pinzgauerlokalbahn.at, 2014).

\section{Rail Passenger Transport and Modal Share}

The number of passenger-kilometres and the modal split reflect the role of rail transport and its popularity, and thus they can be good indicators of their success. It should be emphasised that tendencies in the four analysed countries are different (tables 5 and 6). 
Table 5 The number of rail passenger-kilometres in Poland, the Czech Republic, Slovakia and Austria 2004-2013

\begin{tabular}{crrrr}
\hline Country & \multicolumn{1}{c}{2004} & \multicolumn{1}{c}{2008} & \multicolumn{1}{c}{2012} & \multicolumn{1}{c}{2013} \\
\hline Poland & 18,430 & 19,762 & 17,110 & 16,453 \\
Czech Republic & 6,580 & 6,773 & 7,196 & 7,512 \\
Slovakia & 2,227 & 2,296 & 2,459 & 2,485 \\
Austria & 7,865 & 9,687 & 10,248 & 11,188 \\
\hline
\end{tabular}

Source: Eurostat, http://ec.europa.eu.

Table 6 The modal split of railways in Poland, the Czech Republic, Slovakia and Austria 2004-2013 in \%

\begin{tabular}{crrrr}
\hline Country & \multicolumn{1}{c}{2004} & \multicolumn{1}{c}{2008} & \multicolumn{1}{c}{2012} & \multicolumn{1}{c}{2013} \\
\hline Poland & 8.5 & 8.2 & 6.7 & 6.2 \\
Czech Republic & 7.5 & 7.1 & 8.3 & 8.5 \\
Slovakia & 6.0 & 6.4 & 7.1 & 7.1 \\
Austria & 9.5 & 11.1 & 11.5 & 12.7 \\
\hline
\end{tabular}

Source: Eurostat, http://ec.europa.eu.

Table 7 The share of the number of passengers between Polish railways companies [\%] 2012-2014

\begin{tabular}{lrrr}
\hline \multicolumn{1}{c}{ Company } & \multicolumn{1}{c}{2012} & \multicolumn{1}{c}{2013} & \multicolumn{1}{c}{2014} \\
\hline Koleje Ślaskie & 3.33 & 6.04 & 5.96 \\
Koleje Dolnoślaskie & 0.67 & 0.90 & 1.34 \\
Koleje Wielkopolskie & 1.22 & 2.00 & 2.69 \\
Koleje Mazowieckie & 21.58 & 23.09 & 23.26 \\
SKM Warszawa & 6.30 & 8.35 & 9.51 \\
Arriva & 0.91 & 0.92 & 1,71 \\
PKP SKM Trójmiasto & 13.44 & 13.02 & 13.28 \\
Przewozy Regionalne & 36.88 & 31.39 & 29.48 \\
PKP Intercity & 12.87 & 11.36 & 9.49 \\
Other & 2.80 & 2.93 & 3.28 \\
\hline
\end{tabular}

Source: Urzad Transportu Kolejowego (Polish Office of Rail Transport), www.utk.gov.pl.

Although the number of passengers-kilometres cannot be compared directly due to different size of the countries concerned, clear tendencies in its development can be observed. Whereas in the Czech Republic, Slovakia and particularly in Austria these numbers are growing systematically, Poland is the only country where the role of the railways is diminishing rapidly. This tendency is confirmed by the decreasing modal split of rail - unlike in the other three countries. It is interesting that the most significant negative changes can be observed between 2008 and 2012, i.e. in the period when 2008 the regional services were divested from the national railway company. It seems that then - at least at the beginning - the large scale liberalisation of the Polish railways not only did not stop the decrease of the role of rail transport in the country but even accelerated it. Small role of the non-state rail companies in the Czech Republic and Slovakia and long tradition of private lines in Austria do not enable to analyse these data form the point of view of liberalisation. However, a deeper analysis of the changes in the share of rail passengers between different companies in Poland can be conducted (tab. 7). 
It is significant that the share of all new Polish rail companies is increasing whereas the role of Przewozy Regionalne and PKP Intercity - and the absolute numbers of passengers as well - are falling rapidly. Between 2013 and 2014 the former company lost 5.56 million passengers and the latter 5.18 million (www.utk.gov.pl). By contrast, the number of KolejeMazowieckie passengers increased from 59.106 million in 2012 to 62.448 million in 2013 (Rynek transportu kolejowego w Polsce w 2013 r. - synteza, 2013 and Liczba pasażerów rośnie, ale nie w PKP Intercity, 2014). This tendency would confirm the thesis about greater flexibility of regional government and private companies which manage to attract passengers much better than the (former) monopolist both in- and outside the PKP holding. Although a question arises whether or not is this success of the Koleje Mazowieckie just the effect of the company itself or rather also the result of the large potential of the Warsaw metropolitan area, it is certain that the new regionalowned company is effectively taking advantage of this opportunity.

\section{Economic Versus Political Problems}

Certainly, one of the crucial questions about rail liberalisation is the one about its economic consequences. As far as local railways are concerned, the aim of regional governments which decide to open local rail markets - usually by launching a tender for railway line(s) - is to be able to diminish the subsidies for public transport. The subsidy required by companies which take part in the tender seems often one of the most important - if not the most important - argument when making the final decision. It should be emphasised that the decision to launch the tender is often caused by the demands of the monopolist company to increase the subsidy - as it happened in the Karlovarský kraj in 2006, and in the Kujawsko-Pomorskie voivodeship in 2007. The differences between the subsidies demanded by competing companies can be significant - as is demonstrated by examples from the former region. According to the information of the Czech News Agency (Česká tisková kancelár̆, www.ctk.cz), the winner of the tender in Karlovarský kraj - Viamont company - demanded a subsidy of CZK 64.60 per a kilometre, whereas the monopolist České dráhy as much as CZK 80.40 per a kilometre (www.ctk.cz). Therefore, positive economic consequences of regional rail liberalisation indeed can be observed. In the long term these positive effects for the regional governments are connected not only to less public funds spent on subsidies, but also to the independence from the previous monopolist. In the case of new regional government-owned rail companies in a few Polish voivodeships, this is probably even more important than purely financial profit. This is because at long last the local authorities have obtained the chance to decide about regional rail transport - a thing that was hardly possible under PKP or Przewozy Regionalne monopoly.

In practice, however, not only economic factors decide as the strong position of the monopolist rail company at the national and regional level may impede to open the transport market. The tender in the Podlaskie voivodeship in 2013 can serve as a good illustration of this. The first tender was won by Arriva which demanded a subsidy of $16.70 \mathrm{zl} / \mathrm{km}$ whereas Przewozy Regionalne - $18.05 \mathrm{zl} / \mathrm{km}$. However, the regional government decided to cancel the tender and launch it once again. This resulted in a victory of Przewozy Regionalne but the subsidy proposed this time (14.99 zt/km) seems unrealistic (www.arriva.pl). 


\section{Conclusions}

The regional railway liberalisation in Poland, Czech Republic and Slovakia has been implemented in different circumstances, and consequently has a different scale. It is significant that there is hardly any link between the institutional models of railways chosen by the national authorities and the actual passenger rail liberalisation. In the Czech Republic - which has followed the French model which is not the most favourable towards liberalisation - a few local lines are operated by private companies. This is the result of the first decisions to open the market made by regional governments either in order to reduce the level of subsidy for rail transport (e.g. lines Karlovy Vary Mariánské Lázně and Sokolov - Klingenthal in the Karlovarský kraj) or to maintain any service on the lines which were damaged in natural catastrophes (lines Šumperk - Sobotín / Kouty nad Desnou and Milotice nad Opavou - Vrbno pod Pradědem) or seen as "uneconomical" by the state railways (the narrow gauge lines from Jindrrichův Hradec to Nová Bystřice and Obrataň). The role of private regional railways in the country is still minor as the Czech Railways ČD continue to maintain their dense local network (despite some closures, e.g. in the Pardubický kraj in 2011). Although Slovakia as the only of the analysed countries has chosen complete separation of operator and infrastructure (British model), the role of rail liberalisation in the transport development there can be only described as marginal because just one line has been successfully taken over by a private company so far. It is characteristic that this decision was made by the Ministry and not by the regional authorities. In Poland with its holding model (however with the consequent divestment of the regional services from the national railway company), the railway liberalisation was implemented as an important element of the railway reforms of the first years of the new millenium. Its main result has been the division of the regional passenger service into several competing companies but positive effects (reopening of some lines, however only in some regions) are balanced by isolation of the new regional government-owned systems from each other. Undoubtedly the most positive effect of rail liberalisation in Poland is the improvement in the quality of the services due to large scale rolling stock purchases. However, the difficult economic situation and uncertain future of the PR regional railway company together with the rapid decrease in the number of passengers - even though the latter is balanced by better performance of some regional companies - do not contribute to a generally positive evaluation of the railway liberalisation in Poland. This is because liberalisation itself cannot be seen as a simple remedy for passenger railway problems. The lack of consistent transport policy and the absence of cooperation between the national government, the local authorities and transport companies result in negative trends in railways development in Poland with decreasing number of passengers and modal split of the railways. The reform of the Polish railways in the 2000s and its consequences are probably the best illustration of an urgent need for transport development planning at national and regional level. The examples to follow could be the Czech Republic or Austria where the existence of several private and regional government-owned local railways - which are an indispensable part of the regional transport networks - has contributed to maintain an effective and modern public transport system.

The effects of liberalisation on the local railway networks can often be ambiguous, although the cases of some lines in the Czech Republic, Austria and Poland show that privatisation and municipalisation have a positive effect on the quality of railway ser- 
vice and economic situation of regional governments which have a chance to economise on subsidies are independent form monopolists. It was especially in the case of narrow gauge railway lines that this solution enabled to maintain the service on the sections which were at risk of closure even though new private companies did not succeed in all cases.

However, the liberalisation itself does not provide automatic easy solutions for the local railway problem. It is an important instrument but it should be used as part of the consistent transport policy because the most important condition of the effective transport development seems to be the active cooperation between the railway operators and the local governments.

\section{References}

BARESCH M. (2013), Industrieökonomische Analyse der Liberalisierung des Personenverkehrs der österreichischen Bahn (Diplomarbeit), Johannes Kepler Universität Linz, Institut für Volkswirtschaftslehre Abteilung für Industrieökonomie, [Online] http://www.econ.jku.at/members/Francois/files/LVS-WS13/Dipl_Kap_Baresch.pdf.

BERIA P., QUINET E., DE RUS G., SCHULZ C. (2010), A comparison of rail liberalisation levels across four European countries, Selected Proceedings of the 12th World Conference on Transport Research Society, [Online] http://mpra.ub.unimuenchen.de/29142/.

BOŠKOVIĆ B., BUGARINOVIĆ M. (2015), Why and how to manage the process of liberalization of a regional railway market: South-Eastern European case study, Transport Policy, 41, pp 50-59. DOI: 10.1016/j.tranpol.2015.03.009

BRADSHAW B. (2001), Lessons from a Railway Privatisation Experiment, Japan Railway \& Transport Review, No 29, pp 4-11.

CHARLTON C., GIBB R., SHAW J.(1997), Regulation and continuing monopoly on Britain's railways, Journal of Transport Geography, Vol. 5, No. 2, pp 147-153. DOI: 10.1016/S0966-6923(97)84103-8

DEVILLEX., VERDUYN F. (2012), Implementation of EU legislation on rail liberalisation in Belgium, France, Germany and The Netherlands, National Bank of Belgium. Working Paper Series, No 221.

FINGER M. (2014), Governance of competition and performance in European railways: Ananalysis of five cases, Utilities Policy, 31, pp 278-288. DOI: 10.1016/j.jup.2014.03.003

GÓRNY J. (2013), Kolejowe regionalne przewozy pasażerskie w Polsce w świetle polityki transportowej Unii Europejskiej, Studia i Prace z Geografii i Geologii, nr 32, Poznań: Wydawnictwo Naukowe Bogucki.

GÜTTERMANN F. (2013), Volkswirtschaftliche Effekte der Liberalisierung des Eisenbahnpersonenverkehrs in Österreich. [Online] http://www.akeuropa.eu/de/publicationfull.html?doc_id=300\&vID=43, 2014. 
KNOWLES R. (1998), Passenger rail privatisation in Great Britain and its implications, especially for urban areas, Journal of Transport Geography, Vol. 6, No. 2, pp 117-133. DOI: 10.1016/S0966-6923(98)00005-2

KNOWLES R., HALL D. (1998), Transport Deregulation and Privatisation, Hoyle B., Knowles R., Modern Transport Geography, Chichester, New York, Weinheim, Brisbane, Singapore, Toronto: Wiley\& Sons, pp 75-96.

KOMUSIŃSKI S. (2010), Przeksztatcenia przestrzenne sieci pasażerskiego transportu kolejowego w Polsce w latach 1988-2008, Prace Komisji Geografii Komunikacji PTG, tom XVII, pp 1-140.

RYNEK-KOLEJOWY.PL (2014) Liczba pasażerów rośnie, ale nie w PKP Intercity, [Online]

http://www.rynekkolejowy.pl/51602/liczba_pasazerow_rosnie_ale_nie_w_pkp_intercity.htm, retrieved 4 June 2014, Retrieved 1 April 2014.

MILCZAREK A. (2012), Otwarcie polskiego rynku kolejowego przewozów towarowych i pasażerskich - szanse i zagrożenia, Studia i Prace Wydziału Nauk Ekonomicznych i Zarzadzania Uniwersytetu Szczecińskiego, nr 27, pp 101-123.

OSTAPOWICZ B. (2012), Liberalizacja polityki transportowej Unii Europejskiej, Studia i Prace Wydziału Nauk Ekonomicznych i Zarządzania Uniwersytetu Szczecińskiego, $\mathrm{nr} 27$, pp 77-100.

PAWŁOWSKI J. (2012), Dzieje kolei wąskotorowych na obszarze byłej Zachodniej DOKP, Keller D. (ed.), Dzieje kolei w Polsce, Rybnik: Eurosprinter, Muzeum w Rybniku, pp 185-210.

RAIL LIBERALISATION INDEX 2011. Market Opening: Rail Markets of the Member States of the European Union, Switzerland and Norway in comparison (2011), A study by IBM Global Business Services in conjunction with Prof. Dr.h.c. Christian Kirchner, Humboldt University, Berlin, www.deutschebahn.com, 2014.

RODRIGUE J.-P. (2013), The Geography of Transport Systems, New York: Rouledge, [Online] http://people.hofstra.edu/geotrans/index.html, 2013

VLAKY.NET (2011) Rok zmien 2011: Liberalizácia trhu osobnej železničnej dopravy, [Online] http://www.vlaky.net/zeleznice/spravy/3857-Rok-zmien-2011-Liberalizaciatrhu-osobnej-zeleznicnej-dopravy/, 2014.

RYNEK TRANSPORTU KOLEJOWEGO W POLSCE W 2013- SYNSTEZA (2013), Urząd Transportu Kolejowego, Wydział Analiz, Departament Regulacji Rynku Kolejowego, [Online] www.utk.gov.pl, retrieved 4 June 2014.

SIECIOWY ROZKŁAD JAZDY POCIĄGÓW (Polish Railway Timetable) 2006, 2007, 2008, 2009, 2010, 2011.

TACZANOWSKI, J. (2012), A comparative study of local railway networks in Poland and the Czech Republic,Bulletin of Geography. Socio-economic Series, No. 18, Nicolaus Toruń: Copernicus University Press, pp. 125-138.

TAYLOR Z. (2007), Rozwój i regres sieci kolejowej w Polsce, Warszawa: IGiPZ PAN. 
TOMEŠ Z. (2006), Konkurence na železnici, Národohospodářský obzor, No. 4, pp 97103.

\section{Web pages}

www.akeuropa.eu/de/publication-full.html?doc_id=300\&vID=43, retrieved 3 June 2014 www.arriva.pl, retrieved 1 June 2014

www.ctk.cz, retrieved 12 August 2015

www.econ.jku.at/members/Francois/files/LVS-WS13/Dipl_Kap_Baresch.pdf, retrieved 3 June 2014.

http://ec.europa.eu, retrieved 11 August 2015.

http://www.euroregion-nysa.pl, retrieved 12 August 2015

www.gwtr.cz, retrieved 3 June 2014

http://jhmd.cz/o-nas/historie, retrieved 3 June 2014.

www.jizdni-rady.nanadrazi.cz, retrieved 22 August 2015.

www.kolejedolnoslaskie.eu, retrieved 1 June 2014

http://kolejeslaskie.com, retrieved 1 June 2014

http://koleje-wielkopolskie.com.pl, retrieved 1 June 2014

http://lka.lodzkie.pl, retrieved 1 June 2014

www.malopolskie.pl, retrieved 1 June 2014

www.mazowieckie.com.pl, retrieved 1 June 2014

www.noevog.at, retrieved 3 June 2014

www.pinzgauerlokalbahn.at, retrieved 3 June 2014

www.psmkms.krakow.pl, retrieved 11 August 2015

www.rynek-kolejowy.pl, retrieved 4 June 2014

www.sart.cz/zeleznice-desna/historie, retrieved 3 June 2014

http://spz.logout.cz/trate/vrbno.html, retrieved 3 June 2014

www.utk.gov.pl, retrieved 11 August 2015

www.vlaky.net/zeleznice/spravy/3857-Rok-zmien-2011-Liberalizacia-trhu-osobnejzeleznicnej-dopravy/, retrieved 3 June 2014.

www.zelpage.cz/trate/ceska-republika, retrieved 3 June 2014 